\title{
Pros and Cons of Home Office during the Covid-19 Pandemic
}

\author{
Eliška Obdržálková1, Michala Moravcová2,** \\ ${ }^{1}$ Institute of Technology and Business in České Budějovice, Faculty of Corporate Strategy, Okružní 517/10, 370 01 České Budějovice, \\ Czech Republic \\ ${ }^{2}$ University of Ss. Cyril and Methodius in Trnava, Faculty of Social Sciences, Hajdóczyho 1, 917 01, Trnava, Slovakia
}

\begin{abstract}
Due to the Covid-19 pandemic, many changes have taken place, not only in the economic and health sector but also in the labor market. Many workers had to shift to work from home regardless of their previous experience in having a home office, bringing many challenges and possible benefits and drawbacks. The paper aims to analyze the advantages and disadvantages of the home office trend during the Covid-19 pandemic and their differences in terms of location through a literature review method, synthesis, and subsequent comparison. The research has shown that the most common benefits of working from home include time flexibility, no need to commute, and a reduced risk of contracting the Covid-19. Better communication and physical health are among the least mentioned and therefore the least frequent benefits of the home office trend. The results show that social isolation, work-life balance, and lack of equipment are the most common disadvantages. The least common cons include issues with performing tasks, back pain, or long meetings. In terms of location, the most common advantages and disadvantages vary considerably. In some cases, however, the differences in terms of location were slight to almost non-existent. The findings indicate that it is not clear whether the home office trend and the transition during the Covid19 pandemic are positive or negative, as it has both advantages and disadvantages. They vary in terms of location, which may be due to the different development of countries and cultural differences.

Keywords: home office; working from home; advantages; disadvantages; Covid-19; pandemic
\end{abstract}

\section{Introduction}

In March 2020, a global Covid-19 pandemic was announced. It is a highly infectious viral disease caused by a new type of coronavirus, scientifically named: Severe and Acute Respiratory Syndrome Coronavirus 2 - SARS-CoV-2 [1]. The Covid-19 pandemic is still ongoing and continues to claim many casualties. As this highly infectious disease spreads very quickly, many government measures are being announced to try to reduce the likelihood of infection as much as possible [2]. As reported by Kyzlinková et al. [3], these measures have a significant impact on society in many ways. The pandemic thus brought many changes. Not only in health and economics but also work and employment, for example [4]. Companies in these conditions are forced to react flexibly not only to the competition [5], but also to change the whole setting of the existing operation [6,7]. This also includes product [8], marketing activities [9] and human resource management [10-13].

One of the many measures includes the transition to a home office, which is becoming a particular trend. This measure not only seeks to reduce the risk of Covid-19 infection but also helps employers prevent the loss of the workforce due to quarantine [2]. Most of the workers worked from home, as mentioned by Kyzlinková et al. [3]. The home thus became the workplace for many employees. However, even this trend brings with it many challenges and affects both employers and employees. They were forced to adapt to this change very quickly, often regardless of whether they already had had experience with this form of work [3]. Apart from adaptation, however, it is important to consider some of the risks, ie the negatives and also the positives that the transition to a home office brings. A home office can influence the employees in several aspects. The transition to working from home can affect productivity, both mental and physical health, working hours, money savings, and finally concentration of the employees.

This thesis aims to analyze the advantages and disadvantages of the home office trends during the Covid-19 pandemic and their differences in terms of location.

\section{Literary research}

This is a very topical issue, so the advantage is that the data are more recent. The transition to a home office that can be considered a trend today, and its impact on employees during the Covid-19 pandemic, have been studied by Awada et al. [14]. They obtained the necessary information for the subsequent analysis from the online questionnaire designed and

\footnotetext{
* Corresponding author: michala.moravcova@ucm.sk
} 
executed by them. After analyzing the responses from a total of 988 respondents from 40 states, most of them from California, Awada et al. [14] discovered that productivity at work during the Covid-19 pandemic is not fundamentally different compared to their productivity in the office. However, they said that the benefits of working from home include, for example, improved mental and physical health, better communication with their co-workers, and the comfort of home. They also point to the increased number of working hours, especially among respondents who stated in the questionnaire that they have school-age children [14]. An increase in the number of working hours can be considered a certain disadvantage, ie a negative.

Ipsen et al. [15] similarly dealt with work from home and with working conditions, who after their study concluded that people have a rather positive experience of working from home. This is mainly because they can appreciate the benefits associated with the home office. The study by Ipsen et al. [15] consisted mainly of examining and analyzing the experiences of people from 29 European countries who shifted to a home office. Using an online survey of 5,748 respondents from Europe, they identified the key advantages and disadvantages of working from home. The most frequently mentioned benefits include, for example, reduced risk of spreading COVID-19 and a reduced risk of possible infection, the flexibility of time in terms of breaks and meals, as well as saving time in commuting. Lack of contact with colleagues or going out, poor physical conditions, or lack of necessary equipment were then assessed as the most common and most important disadvantages of working from home [15]. Using an online questionnaire with thousands of respondents from Italy and subsequent analysis of the answers, Bolisani et al. [16] pointed out that it is not possible to state unequivocally whether working from home is more advantageous or vice versa, mainly due to the balance between positive and negative opinions of workers working from home during the Covid-19 pandemic. They also gave various examples of disadvantages such as the inability to suspend long meetings and isolation from colleagues. On the contrary, better focus on work or the possibility of one 's meals are some of the aspects that favor working from home [16]. One of the unusual aspects that affect employee satisfaction and productivity when working from home during a pandemic is also noise. This factor was addressed by Puglisi et al. [17]. Through an online questionnaire on perceived noise in the workplace, with a total of 1,934 respondents also from Italy, they concluded that noise nuisance, which occurs mainly in employees working in the same room with other members of the household, has a negative effect on concentration, attention, or relaxation [17]. These effects can be considered as disadvantages of working from home and therefore noise is one of the possible negatives of the home office.

Using the same method, i.e., by investigating and subsequently analyzing the responses from the respondents, Grossmann et al. [2] confirm some positive experiences with working from home. They cite, for example, the need for commuting, time flexibility, or, for example, focusing on work as the best-rated benefits [2]. Chen [18] also mentions many identical advantages and disadvantages of working from home during the Covid-19 pandemic in their study of the impact of working from home on employees. Based on other expert studies and surveys, Chen [18] concluded that, among other things, insufficient skills of employees, uncertainty about redundancies, wage cuts, and bankruptcies are some of the significant negatives of working from home for employees. For managers, for example, it is the inability to thoroughly control and supervise subordinates or the lack of interaction with them [18].

Mehta [19] examined whether the work commitment and happiness of employees working from home during the Covid-19 pandemic was at the same level as before the pandemic, and thus in line with previous studies. Thanks to responses from 440 respondents in India, the study shows that working from home during the aforementioned pandemic has a significant impact on employee happiness. Mehta [19] further states that employees feel more involved in their work, mainly because working from home allows them independence and comfort. These aspects have a positive effect on their work commitment, and this leads to happiness [19].

Based on the already available data of current sample surveys, Kyzlinková et al. [13] conclude that employees perceive working from home differently, not only positively. However, it is worth noting that the move to a home office has helped mitigate some of the negative effects of the Covid-19 pandemic, both in terms of economics and health. Other positive impacts include time flexibility, restrictions on commuting to work and the associated time savings, work performance without interruption, or savings in the employer's operating costs [13]. They thus identify with most of the advantages reported by Grossmann et al. [2]. The absence of contact with colleagues, social isolation, problems with the organization of time, and complications in fulfilling the task, then Kyzlinková et al. [13] specify working from home as the main disadvantages. Identical or at least very similar advantages and disadvantages of working from home are confirmed by a study of the Ministry of Labor and Social Affairs of the Czech Republic [20], which examined the experience of employees and employers from the Czech Republic with working from home during the Covid-19 pandemic. Among other things, they also stated that the possibility of working at least partially from home for most respondents has a positive effect on mental health and family life [20]. Pfeifer [21] also examined the mental health and hard work of Czech employees and managers during the Covid-19 pandemic by analyzing a questionnaire with 174 answers. He came to a somewhat different opinion than, for example, the Ministry of Labor and Social Affairs of the Czech Republic. According to the results of the survey, employees and managers fall into mental stress when working from home, which negatively affects their mental health [21]. Pfeifer [21] stated that the reason may be the often-mentioned increased sensitivity to social isolation. It is also a very interesting finding that the mental health and desire to work for employees working from home during the Covid-19 pandemic depends on whether the lockdown is ordered. At the time of the lockdown, the desire to work is up to $20 \%$ lower and the sensitivity to social isolation is higher [21]. 
In addition to the advantages and disadvantages, Okuyan and Begen [22] have discussed recommendations and measures that will help eliminate some of the disadvantages and thus have a positive effect on working from home during the Covid-19 pandemic, based on information from other professional monographs and surveys. These include, for example, setting a border between work and personal life through breaks and pre-determined daily routines, which can prevent obesity or an imbalance between work and personal life [22]. Rieth and Hagemann [23] also agree with the fact that the issue of work-life balance is a disadvantage of working from home. Using an online survey, they obtained answers from 465 employees from Germany and focused on the conflict between family and work, besides other factors, during the pandemic. The results show that people who have children at home in the home office experience significantly more stress, a greater loss of concentration, and thus consider working from home to be rather negative [23]. Among other things, this disadvantage may be related to emotional exhaustion and burnout in employees working from home during the Covid-19 pandemic [4]. Barriga et al. [4] used an online questionnaire with 1,044 respondents from South America, specifically Ecuador, to observe and analyze the influence of conflict between work and family on the burnout syndrome, emotional exhaustion during the home office. The results showed that working from home has a negative effect on worklife balance, so they are also consistent with a study by Irawanto et al. [24], who came to this conclusion based on an analysis of responses from 472 respondents from Indonesia.

The coronavirus crisis and work at this time, especially work from home, were dealt with by López Peláez et al. [25], who came up with unique and interesting advantages of the transition to a home office. Thanks to working from home, there is greater digitalization and innovation in which it is appropriate to emphasize their availability or functionality and can therefore be considered as positives of working from home. Thanks to the data and information from other expert surveys and subsequent analysis, López Peláez et al. [25] discovered that remote work is an indicator of greater digitalization and contributes to improving the economic results of companies. Whether the positives and negatives of working from home during a pandemic differed by gender were examined by Khan and Umer [26] through an online questionnaire with 222 respondents from Japan and the United States. After analyzing the answers, they concluded that the advantages include more men than women, money saved for non-commuting, as well as the comfort of home [26]. According to Khan and Umer [26], this may be because women with children sometimes must take care of family or housework during working hours. A significantly higher proportion of men than women cited fewer business meetings as an advantage. There are no significant gender differences in the negatives, or challenges, that employees face when working from home [26].

Farooq and Sultana [27] and subsequently Guler et al. [28], who have a completely different view on this issue, also examined the transition to a home office and its impact on employees' productivity. Using an online questionnaire with 250 Indian respondents, Farooq and Sultana [27] examined employee productivity at home and aspects that could affect their productivity. They analyzed the responses and concluded that working from home during the Covid-19 pandemic, employee productivity declined, and the results showed that it had a greater impact on productivity for women than for men. Decreasing productivity could be caused, for example, by ineffective communication, which respondents often mentioned [27]. Guler et al. [28], who, using the same method and also based on the analysis of answers from 149 respondents, concluded that employee productivity did not decrease after the transition to a home office, but on the contrary, increased. Their work was of better quality and more efficient [28]. Guler et al. [28] in their study also focused on the health of home workers and reported interesting effects such as weight gain or complaints of back and neck pain. Thus, musculoskeletal pain can also be mentioned as a negative.

Regarding the counterproductive work behavior of employees working from home during the Covid-19 pandemic and whether the home environment has an impact on this factor have been investigated by Nemteanu et al. [29]. The data on which they based their study were collected from 641 employees from Romania through an online questionnaire [29]. According to Nemteanu et al. [29,p.601] "remote work significantly and strongly affects professional isolation and to a lesser extent, but still significantly, counterproductive work behavior and the ability of self-regulation of employees".

\section{Methodology}

As already mentioned, the home office trend, which spread widely during the COVID-19 pandemic, has many advantages and disadvantages. This thesis aims to analyze the advantages and disadvantages of the home office trends during the Covid-19 pandemic and their differences in terms of location. To achieve the goal, it is necessary to ask the following research questions.

1. What are the advantages and disadvantages of working from home during the Covid-19 pandemic and what are the least common ones?

\section{Are there any differences in advantages and disadvantages in terms of location?}

The basic source of data will be articles from the citation databases Web of Science and Scopus. It will therefore be a literature review. Using Covid-19 keywords, pandemics, home office, working from home, advantages and disadvantages, possible relevant resources are sought and further analyzed. The sources that analyze the advantages and disadvantages of working from home during the Covid-19 pandemic using empirical research are selected. The respondents to the analyzed studies come mainly from Europe. However, some data are obtained from respondents from around the world. 
For example, from Asia, mostly from India, Indonesia and Japan. Or, for example, from respondents from South and North America.

With the help of keywords Covid-19, pandemics, home office, work from home, advantages, and disadvantages, resources are researched from the citation databases Web of Science and Scopus. About 150 professional publications are displayed, from which only a few relevant sources are selected that meet a certain criterion. Resources need to include an analysis of the pros and cons of working from home during the Covid-19 pandemic. Thus, we work with sixteen professional articles that meet this criterion. These sources are then examined for the already mentioned advantages and disadvantages of the home office, frequently mentioned in the results, then in the discussion of the results and the conclusion. Next, a synthesis of selected advantages and disadvantages is done. They are recorded in a spreadsheet editor in Excel and then compared using statistical and logical functions. Subsequently, the results are examined based on absolute and relative frequency. Furthermore, the advantages and disadvantages are divided in terms of location. Of the sixteen sources, only twelve are used, for which the location is given and thus meets the criterion. The resources are divided in terms of location into two parts, namely Europe and the other continents. Therefore, it works with seven sources from Europe and five sources from other continents. Due to the unbalanced distribution, it is calculated based on relative frequency, with seven sources with respondents from Europe representing $100 \%$ and five sources with respondents from other continents also representing 100\%. The results are displayed in tables, followed by the final comparative research method, which determines the differences in advantages and disadvantages in terms of location.

\section{Results}

As shown in Figure 1, some benefits of working from home during the Covid-19 pandemic have been mentioned more frequently. The highest percentage achieves the advantage of time flexibility. This is a $20 \%$ representation. The advantage of no need to commute and the associated savings is $17 \%$. Another benefit of working from home was health, i.e., a reduced risk of contracting the Covid-19 virus. The advantage of the reduced risk of infection was mentioned by up to five professional articles, which is only two less than the need for commuting and thus reaches up to $13 \%$ representation. Better concentration, as an advantage of the home office trend, also reaches $13 \%$. Other analyzed benefits of working from home are the comfort of home and more time spent with the family. These advantages have been mentioned in four academic publications and represent the $10 \%$. The last benefits, which have achieved at least one repetition, and have therefore been mentioned in at least two articles, are better mental health, the ability to prepare food on one's own, and independence reach 5\%. The remaining benefits were mentioned in only one of the academic articles used. In chart one, they are referred to as "other benefits" and acquire only $3 \%$, thus reaching the lowest percentage.

\section{Advantages of working from home during Covid-19}

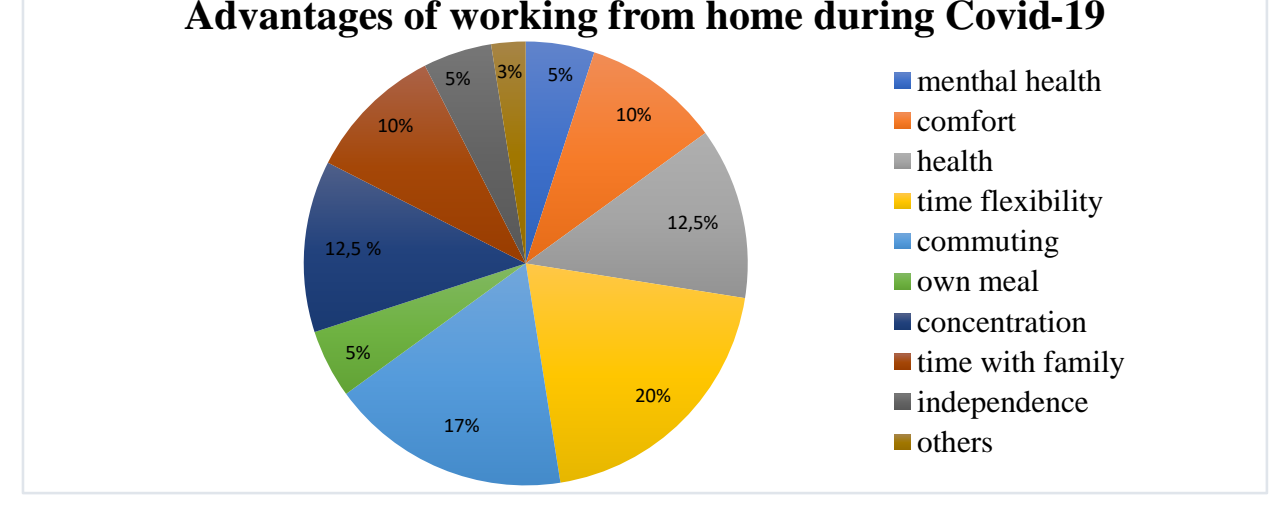

Figure 1. The most common advantages of working from home during Covid-19

Source: Authors.

Figure 2 shows the disadvantages of working from home during the Covid-19 pandemic and their percentage. The highest percentage is achieved by the disadvantage of social isolation, which is $19 \%$. The following disadvantage, the imbalance of personal and professional life, was mentioned in up to five sources used and thus reaches up to $16 \%$ of the representation. Three percent less, ie 13\%, achieved the disadvantage of lack of equipment, which was mentioned in four selected professional sources. Other disadvantages that appeared in multiple references were the lack of contact with colleagues and obesity or weight gain. Specifically, they were mentioned in three professional articles that meet the criteria and reach up to $10 \%$. Only two sources mentioned more disadvantages, which include an increased number of working hours, possible technical problems, more stress, lack of concentration, and poor communication. These disadvantages amount to $6 \%$ and are fewer common disadvantages. The remaining disadvantages were always mentioned in only one of the sources used. In Figure 2, they are marked as "other" and reach only $3 \%$. 


\title{
Disadvantages of working from home during Covid-19
}

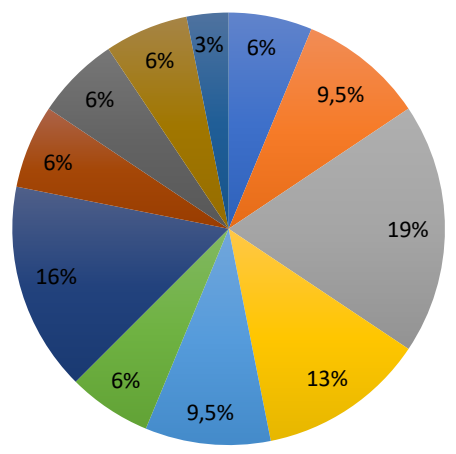

\author{
- Increased working hours \\ absence of contact with colleagues \\ social isolation \\ lack of equipment \\ obesity \\ - technical problems \\ - lack of work-life balance \\ a stress \\ noise \\ - poor communication \\ athers
}

Figure 2. The most common disadvantages of working from home during Covid-19

Source: Authors.

Regarding the differences in advantages and disadvantages of working from home during the Covid-19 pandemic in terms of location, there are certain differences, which are shown in the tables below. Table 1 shows the differences in benefits. Table 1 shows that there are significant differences in the benefits of time flexibility mentioned in five of the seven sources that analyze the responses of European respondents and thus reach up to $71 \%$ of the representation. While respondents from other continents have not mentioned this advantage once and it is $0 \%$. The difference in terms of location is significant for this advantage. Significant differences in terms of location are also in the advantage of the lack of commuting, which is more common in Europe than in other parts of the world. In Europe, this advantage is $71 \%$. However, as can be seen from Table 1, the difference in terms of location is $31 \%$ smaller than in terms of time flexibility, as it is at least $40 \%$ on other continents. Similarly, there are benefits such as the ability to prepare one's meal and better concentration. Both of these benefits were mentioned only by respondents from Europe. However, respondents from other continents did not address these benefits. As can be seen in the table, the difference in terms of location is $29 \%$ for the benefit of preparing one's meals and $57 \%$ for better concentration. On the contrary, the advantages that were more often mentioned by respondents from other continents are the comfort of home and independence. In other continents, home comfort benefits up to $60 \%$, compared to only $14 \%$ in Europe. It is very similar for independence, where the difference in terms of location is $40 \%$. For the remaining advantages, the differences in terms of location are only slight. This is a benefit of the reduced risk of contracting the Covid-19 virus and the more time spent with the family. For both advantages, the difference in terms of location is only $11 \%$.

Table 1. Differences in advantages in terms of location

\begin{tabular}{|l|c|c|}
\hline \multicolumn{1}{|c|}{ Advantages } & Europe & Other continents \\
\hline Lower risk of Covid-19 infection & $29 \%$ & $40 \%$ \\
\hline Time flexibility & $71 \%$ & $0 \%$ \\
\hline Commuting & $71 \%$ & $40 \%$ \\
\hline Own meal & $29 \%$ & $0 \%$ \\
\hline Concentration & $57 \%$ & $0 \%$ \\
\hline Comfort & $14 \%$ & $60 \%$ \\
\hline More time with family & $29 \%$ & $40 \%$ \\
\hline Independence & $0 \%$ & $40 \%$ \\
\hline
\end{tabular}

Source: Authors.

Table 2 shows the disadvantages of working from home during the Covid-19 pandemic and their differences in terms of location. Table 2 shows that there are slightly fewer disadvantages than the advantages listed in Table 1 . The disadvantage - social isolation points to many differences. This disadvantage was mentioned in five sources analyzing the responses of European respondents and accounts for $71 \%$ of Europeans. Whereas respondents from other parts of the world have been mentioned only once, reaching only $20 \%$ across the other continents. In terms of disadvantages, this is the biggest difference in terms of location, namely a $51 \%$ difference. The disadvantage, which was also mentioned by more respondents from Europe, was the absence of contact with colleagues. However, for this disadvantage, the difference in terms of location is only $9 \%$ and is therefore much smaller than for the disadvantage of social isolation, as can be seen in Table 2. Disadvantages more often mentioned by respondents from other continents are imbalance between personal and professional life and poor communication. The disadvantage of a lack of work-life balance is $40 \%$ on other continents, 
compared to only $14 \%$ in Europe. The difference in terms of location is therefore $26 \%$. At the disadvantage of poor communication, the difference is even greater, namely $14 \%$, as it was not mentioned by European respondents at all. The difference in this disadvantage in terms of location is therefore $40 \%$. As can be seen from Table 2 , for the remaining disadvantages, such as lack of concentration, technical problems, lack of equipment, and increased working hours, the differences in terms of location are insignificant. The difference is always around $6 \%$ or a maximum of $11 \%$.

Table 2. Differences in disadvantages in terms of location

\begin{tabular}{|l|c|c|}
\hline \multicolumn{1}{|c|}{ Disadvantages } & Europe & Others continents \\
\hline Social isolation & $71 \%$ & $20 \%$ \\
\hline Absence of contact with colleagues & $29 \%$ & $20 \%$ \\
\hline Lacko of concentrationt & $14 \%$ & $20 \%$ \\
\hline Technical problems & $14 \%$ & $20 \%$ \\
\hline Lacko of equipment & $29 \%$ & $40 \%$ \\
\hline Lacko of work-life balance & $14 \%$ & $40 \%$ \\
\hline Poor communication & $0 \%$ & $40 \%$ \\
\hline Increased working hours & $14 \%$ & $20 \%$ \\
\hline
\end{tabular}

Source: Authors.

\section{Discusssion}

Based on the results, we are now able to answer the research questions that have been set.

First research question: What are the advantages and disadvantages of working from home during the Covid-19 pandemic and what are the least common ones?

The most common advantage of working from home during a Covid-19 pandemic is time flexibility, which reaches $20 \%$ representation. I think that thanks to the flexibility of time, they can schedule their working hours so that they have more time for their family and household chores, for example. As can be seen from Figure 1, the second most common advantage with a $17 \%$ share is the need for commuting and the associated savings. It is a matter of saving time and then, above all, of saving money. The following very common benefits of working from home during a Covid-19 pandemic are health, i.e., a reduced risk of Covid-19 virus infection and better concentration. Both benefits have been mentioned in up to five professional articles and amount to $13 \%$. In addition to the reduced risk of infection with the virus, there is also the advantage of a reduced risk of spreading the virus. Better concentration can then be caused, for example, by less frequent disturbances, which in my opinion can be caused in the workplace by, for example, co-workers or customers. Other frequently mentioned benefits are the comfort of home and more time spent with the family. The comfort of the home could positively affect the concentration of employees in the home office, and more time spent with the family can be ensured by the aforementioned time flexibility.

Productivity, for example, is one of the least common benefits of working from home during a Covid-19 pandemic. This may be the least common advantage, for example, because productivity at work during the Covid-19 pandemic may not differ significantly from their productivity in the office, as mentioned by Awada et al. [14]. The other least common benefits are also digitalization, better communication, and physical health. These least common benefits are included in the results and Figure 1 as "other" and have therefore always been mentioned in only one of the sources. They reach only $3 \%$. The advantages, which were mentioned in two sources and gain 5\%, are better mental health, independence, and the possibility of preparing one's meal. Even these benefits can still be described as less common.

The most common disadvantage of working from home during the Covid-19 pandemic is social isolation. Social isolation has been reported by many sources and is as high as 19\%, as shown in Figure 2. I think that social isolation can trigger mental problems and thus negatively affect the health and productivity of workers from home. The second most common disadvantage with $16 \%$ representation is the imbalance between personal and professional life. This can be caused mainly by poor scheduling of working hours. Homeworkers, for example, work at a time when they can take care of their family or vice versa. Therefore, as Okuyan and Begen [22] have pointed out, it is appropriate to avoid this disadvantage by more frequent breaks and better working time arrangements. Another often mentioned disadvantage is the lack of equipment, which represents $13 \%$. Lack of equipment is a problem that does not facilitate the job. In my opinion, the employer should properly address this situation and provide their employee with suitable conditions, including all the equipment for the room in which the work is performed. The last common disadvantages include the lack of contact with colleagues and weight gain or even obesity caused by reduced activity representing up to $10 \%$.

The least common disadvantages of the home office trend during the Covid-19 pandemic are complications in performing tasks, poor organization of time, or back pain caused by inappropriate equipment. Further, there are too long meetings. These disadvantages are marked as "other" in the results and were always mentioned in only one of the sources used. They reach only 3\%, as can be seen from Figure 2 . 
These are the least mentioned disadvantages, in my opinion mainly because they are very individual facts. Every employee working from home has different equipment, different lengths of meetings, and different management, ensuring the least possible risk of complications in performing tasks. This individuality may be the result of a minimal mention of these disadvantages. Other uncommon disadvantages are often increased working hours, technical problems, and more stress. Furthermore, poor concentration and communication are also categorized as purely individual matters. The concentration depends mainly on the environment in which they perform their work. Whether it is a shared room like the living room or a private room where no one is disturbed at work. All these disadvantages reach $6 \%$, as can be seen in Figure 2 .

\section{Second research question: What are the differences in advantages and disadvantages in terms of location?}

Some differences in the advantages and disadvantages of working from home during the Covid-19 pandemic remained significant in terms of location. However, for some advantages and disadvantages, the differences were small or almost non-existent. The biggest differences in terms of location were the advantages of time flexibility and the disadvantages of social isolation. Both benefits were mentioned in up to five sources with respondents from Europe, while from other continents only once or not at all.

As can be seen from Table 1, the advantage of time flexibility is a difference of $71 \%$ in terms of location. As can be seen from Table 2 , the difference in social isolation is $51 \%$, slightly smaller than the flexibility of time. Nevertheless, it is a disadvantage with the greatest differences in terms of location. The fact that the biggest differences in terms of location are precisely the advantages and disadvantages is very interesting, as the first research question led us to the conclusion that these are the most common advantages and disadvantages of working from home during the Covid-19 pandemic. Therefore, I would expect them to be mentioned frequently by respondents from all over the world, not just or mainly from Europe. There were also significant differences in the benefits of better focus on work and the need for commuting associated with saving time and money. Even these benefits were mentioned mostly only by respondents from Europe. The difference in work focus was $57 \%$. With no need to commute, as can be seen from Table 1 , the difference was slightly smaller than with better concentration. Among the last advantages and disadvantages, which generally vary considerably in terms of location, are the advantages of home comfort and independence, as well as the disadvantage of poor communication. Other disadvantages and advantages are no longer so different in terms of location and the differences are slight. It is remarkable that the comfort of home and independence, as positives of working from home and the disadvantage of poor communication, have, on the contrary, been more widespread on other continents than in Europe. The advantage of independence and the disadvantage of poor communication reach up to $40 \%$ representation on other continents, while 0\% representation in Europe. With the benefit of home comfort, as can be seen from Table 1, the difference is slightly smaller, as it accounts for at least $14 \%$ of Europe. The differences in the remaining advantages and disadvantages were only slight. This is the case, for example, with the advantage of a reduced risk of infection with the Covid-19 virus, where the difference was only $11 \%$. I assumed this fact because it is a global pandemic and therefore this advantage is very important for everyone.

\section{Conclusion}

This thesis aims to analyze the advantages and disadvantages of the home office trend during the Covid-19 pandemic and the differences in terms of location. Using a literature review study, a subsequent synthesis of advantages and disadvantages, and a comparative method, the most common and, conversely, the least frequent advantages and disadvantages of working from home during the Covid-19 pandemic and their differences in terms of location were identified.

It is not possible to determine exactly whether the transition to a home office trend during the Covid-19 pandemic is exclusively positive or negative, as it has its advantages and disadvantages. However, it can be stated that the most common disadvantages of working from home include social isolation and lack of contact with colleagues, which, however, may depend on whether or not a state of emergency is declared and the associated limited movement of persons. The least common disadvantages of the home office trend in the Covid-19 pandemic are, for example, poor communication and lack of concentration. The consequence may be that this is a very individual matter, as some sources, on the contrary, mentioned concentration as a positive. As for the benefits of working from home during the Covid-19 pandemic, the most common is time flexibility, which is appreciated the most by the employees. Further, there is also no need to commute as a time and money saver. Also a reduced risk of Covid-19 infection, which is likely in a pandemic. This benefit, which affects our health, is no different in terms of location, as it is a global pandemic and therefore valuable benefits from employees around the world. While for the other advantages and disadvantages already mentioned, apart from the lack of concentration, considerable inconsistencies, and differences in terms of location were found. Many of the most common advantages and disadvantages were mentioned by many more respondents from Europe than from other parts of the world. Differences in advantages and disadvantages in terms of location may be due to the different development of countries and cultures. Last but not least, the least common benefits are the comfort of home and more time with the family.

The above results inevitably lead to the question of what causes the differences in advantages and disadvantages in terms of location. What measures can lead to minimizing disadvantages? Based on the data and content that has been 
collected and used for this research, it is not possible to answer these questions. It is therefore recommended to carry out follow-up research, which can build on the data and results of this study and answer the questions for better understanding.

\section{Acknowledgments}

This work was supported by the grant VEGA (No. 1/0038/22) Application of competitive digital games for the team cohesion development and social adaptation of Generation Z.

\section{References}

1. L. Yang, S. Liu, J. Liu, Z. Zhang, X. Wan, B. Huang, Y. Chen, Y. Zhang. COVID-19: Immunopathogenesis and Immunotherapeutics. Signal Transduction and Targeted Therapy. 5(1) doi:10.1038/s41392-020-00243-2 (2020)

2. J. Grossmann, V. Korbel, D.Münich. Práce z domova: možnost, nebo nutnost? Praha: Národohospodářský ústav AVČR. ISBN 978-80-7344-572-0 (2021)

3. R. Kyzlinková, S. Veverková, H. Vychová. Práce z domova - popis stavu před pandemií a možné konsekvence do nových poměrů organizace práce. Fórum sociální politiky. 48(5), (2020)

4. M. Barriga, R. Holger, R. C. Aguirre, D. Coello-Montecel, P. O. Pacheco, M. I. Paredes-Aguirre. The Influence of Work-Family Conflict on Burnout during the COVID-19 Pandemic: The Effect of Teleworking Overload. International Journal of Environmental Research and Public Health. 18(19) doi:10.3390/ijerph181910302 (2021)

5. P. Kalina. Change Management: COVID-19 and Beyond. Journal of Human Resource Management. 23(1), 38-40 (2020)

6. D. Lazarević, M. Dobrodolac, L. Švadlenka, B. Stanivuković. A model for business performance improvement: A case of the postal company," J. Bus. Econ. Manag., 21(2), 564-592 doi: 10.3846/jbem.2020.12193 (2020)

7. J. Jaros, V. Melichar, L. Svadlenka. Impact of the Financial Crisis on Capital Markets and Global Economic Performance-Web of Science Core Collection. Transport Means - Proceedings of the International Conference. 431-434 (2014)

8. L. Č́byová, P. Krajčovič. The role of SoLoMo marketing and media in the communication of eco-innovations. $1^{\text {st }}$ ed. Budapešt': Wolters Kluwer. ISBN 978-963-295-952-8 (2020)

9. J. G. Matúšová. Logo as the Greatest Symbol of Brand. European Journal of Media, Art \& Photography. 9(2), 126$133(2021)$

10. K. Stachová, J. Blštáková, Z. Stacho. Riadenie l’udí v digitálnej a post-pandemickej dobe. $1^{\text {st }}$ ed. Praha: Wolters Kluwer. ISBN 978-80-8078-606-9 (2021)

11. M. Hitka, Z. Balazova, V. Grazulis, P. Lejskova. Differences in Employee Motivation in Selected Countries of CEE (Slovakia, Lithuania and the Czech Republic). Inzinerine Ekonomika-Engineering Economics. 29(5), 536-547 doi: 10.5755/j01.ee.29.5.13953 (2018)

12. M. Hitka, Z. Rózsa, M. Potkány, L. Ližbetinová. Factors forming employee motivation influenced by regional and age-related differences. Journal of Business Economics and Management. 20(4), 674-693 doi: 10.3846/jbem.2019.6586 (2019)

13. L. Krejčí, Š. Doleželová. Systematizace ne-řidičských činností řidičů autonomních nákladních vozidel. Perner's Contacts, 16(1). https://doi.org/10.46585/pc.2021.1.1662 (2021).

14. M. Awada, G. Lucas, B. Becerik-Gerber, S. Roll. Working from home during the COVID-19 pandemic: Impact on office worker productivity and work experience. Work. 69(4), 1171-1189 doi:10.3233/WOR-210301 (2021)

15. C. Ipsen, M. van Veldhoven, K. Kirchner, J. P. Hansen. Six Key Advantages and Disadvantages of Working from Home in Europe during COVID-19. International Journal of Environmental Research and Public Health. 18(4) doi:10.3390/ijerph18041826 (2021)

16. E. Bolisani, E. Scarso, C. Ipsen, K. Kirchner, J.P. Hansen. Working from home during COVID-19 pandemic: lessons learned and issues. Management \& Marketing. Challenges for the Knowledge Society. 15(s1), 458-476 doi:10.2478/mmcks-2020-0027 (2020)

17. G. E. Puglisi, S. Di Blasio, L. Shtrepi, A. Astolfi. Remote Working in the COVID-19 Pandemic: Results From a Questionnaire on the Perceived Noise Annoyance. Frontiers in Built Environment. 7 doi:10.3389/fbuil.2021.688484 (2021)

18. Z. Chen. Influence of Working From Home During the COVID-19 Crisis and HR Practitioner Response. Frontiers in Psychology. 12 doi:10.3389/fpsyg.2021.710517 (2021) 
19. P. Mehta. Work from home-Work engagement amid COVID-19 lockdown and employee happiness. Journal of Public Affairs. doi:10.1002/pa.2709 (2021)

20. MPSV ČR. Práce z domova: Zkušenosti zaměstnanců a vedoucích pracovníků v souvislosti s nárůstem využivání práce $z$ domova během pandemie koronaviru [online]. Available at: https://www.esfcr.cz/documents/21802/14776072/Vyhodnocen\%C3\%AD+dotazn\%C3\%ADku+Pr\%C3\%A1ce+z +domova.pdf/99450e64-d6a5-453a-82ca-a5ddd1dd6b23

21. M. R. Pfeifer. Human Resources during COVID-19: A Monthly Survey on Mental Health and Working Attitudes of Czech Employees and Managers during the Year 2020. Sustainability. 13(18) doi:10.3390/su131810055 (2021)

22. O. B. Okuyan, M. A. Begen. Working from home during the COVID-19 pandemic, its effects on health, and recommendations: The pandemic and beyond. Perspectives in Psychiatric Care. doi:10.1111/ppc.12847 (2021)

23. M. Rieth, V. Hagemann. The Impact of Telework and Closure of Educational and Childcare Facilities on Working People During COVID-19. Zeitschrift für Arbeits- und Organisationspsychologie A\&O. 65(4), 202-214 doi:10.1026/0932-4089/a000370 (2021)

24. D. Irawanto, K. Novianti, K. Roz. Work from Home: Measuring Satisfaction between Work-Life Balance and Work Stress during the COVID-19 Pandemic in Indonesia. Economies. 9(3) doi:10.3390/economies9030096 (2021)

25. A. López Peláez, A. Erro-Garcés, F. J. P. García, D. Kiriakou. Working in the 21 st Century. The Coronavirus Crisis: A Driver of Digitalisation, Teleworking, and Innovation, with Unintended Social Consequences. Information. 12(9) doi:10.3390/info12090377 (2021)

26. M. S. Khan, H. Umer. Benefits and Challenges of COVID-19 Induced Telework Across Gender: Policy Lessons for Sustainable Future Telework. SSRN Electronic Journal doi:10.2139/ssrn.3848640 (2020)

27. R. Farooq, A. Sultana. The potential impact of the COVID-19 pandemic on work from home and employee productivity. Measuring Business Excellence. doi:10.1108/MBE-12-2020-0173 (2021)

28. M. Guler, A.K. Guler, M. G. Gulec, E. Ozdoglar. Working From Home During a Pandemic. Journal of Occupational \& Environmental Medicine. 63(9), 731-741 doi:10.1097/JOM.0000000000002277 (2021)

29. M. S. Nemteanu, D. C. Dabija, L. Stanca. The Influence of Teleworking on Performance and Employees. Counterproductive Behaviour. 23(58) doi:10.24818/EA/2021/58/601 (2021) 